\title{
History of Mathematics for Teaching Mathematics: The Case of Indonesian Prospective Teachers' Beliefs and Attitudes
}

\author{
Intan Bigita Kusumawati ${ }^{1}$, Achmad Dhany Fachrudin ${ }^{1, *}$, Ahmad Wachidul Kohar ${ }^{2}$, Soffil Widadah ${ }^{1}$ \\ ${ }^{1}$ Department of Mathematics Education, STKIP PGRI Sidoarjo, Indonesia \\ ${ }^{2}$ Department of Mathematics, Universitas Negeri Surabaya, Indonesia
}

Received February 23, 2020; Revised April 23, 2020; Accepted May 3, 2020

Copyright $\odot 2020$ by authors, all rights reserved. Authors agree that this article remains permanently open access under the terms of the Creative Commons Attribution License 4.0 International License

\begin{abstract}
The inclusion of History of Mathematics (HoM) in the official mathematics textbook published by Indonesian Ministry of Education and Culture became an essential aspect in supporting the national curriculum of mathematics education. This study aimed to examine Indonesian prospective mathematics teachers' pedagogical attitudes and beliefs in using HoM to teach mathematics. 305 prospective teachers from nine universities in Indonesia were involved as the respondents. Data were collected using Questionnaires of Attitude and Belief in using HoM to teach mathematics. The results showed that prospective teachers had positive attitudes and beliefs in using HoM to teach mathematics. However, those who had taken the mathematics history course tent to have a higher score compared to those who had not taken the course yet during their study times. Hence, this study recommends that involving the HoM course is vital in supporting the prospective teachers' learning process as a part of their future professional developments. However, both groups showed low scores in the questionnaire item of self-efficacy beliefs. This implies that teacher education programs should facilitate the improvement of prospective teachers' self-efficacy beliefs and skills, especially of using HoM in teaching mathematics.
\end{abstract}

Keywords History of Mathematics, Indonesian Prospective Teacher, Beliefs and Attitude, Teaching Mathematics

\section{Introduction}

Numerous studies, which discussed the role of history of mathematics in mathematics education, point out various categories and arguments of using the history of mathematics (HoM) in mathematics education. Jankvist (2009) provided two categories of utilizing HoM in mathematics learning process, namely the "Why" and "How" categories. In connection with the "why" category, Jankvist (2009) conveyed that the category focused on the indispensable argument of HoM in mathematics education. Other studies investigate the effect of using HoM in classroom activities on prospective teacher's mathematics knowledge (Clark, 2012; Furinghetti, 2007). Those two studies emphasize the importance of HoM in mathematics education for the teacher education program and prospective teacher. Moreover, Alpaslan, Isıksal \& Haser (2014) studied the relationship between knowledge, attitudes, and beliefs and using HoM for teacher education programs in Turkey. This study leads us to conduct a similar research, however, for the case of Indonesian prospective teachers.

In Indonesia, HoM has not been explicitly integrated in Indonesian secondary school. However, studies related to it in mathematics education, especially at the secondary school level, have been addressed by some researchers. Ekawati, Fiangga, \& Siswono (2018) analyzed how the Indonesian Mathematics' textbook integrated with the history of mathematics (HoM) enhanced students' understanding of mathematics concept. Fachrudin \& Putri (2014) studied the role of ancient geometric method in supporting students' understanding about the quadratic equation. All of these studies suggested that the use of HoM in classroom activities was important due to the fact that it could improve student's understanding by the assistance of prospective teachers' relevant abilities and correct perceptions. Therefore, a study about prospective teachers' knowledge about HoM and how their attitudes and beliefs in using it in mathematics education was required to undertake in advance to determine further steps of integrating HoM in mathematics education in Indonesia. 
In attempt to reveal the potential benefits of HoM in teaching mathematics, some programs by utilizing it have been conducted. For examples, Fachrudin et al (2018) developed an instructional design to produce a learning trajectory for Pythagorean Theorem using Babylonian approach under design-based research method. Moreover, Wang et al (2018) introduced a framework of a design-based procedure to integrate $\mathrm{HoM}$ in an instructional design, covered in an operating model consisting five cyclic stages namely investigation, design, implementation, assessment, and publication. In relation with other approaches to learn mathematics using HoM, Bütüner (2016) found that using concrete learning objects from HoM could improve student's learning attainment in mathematics. In addition, Zangin (2018) portrayed that the use of technology within a dynamic software could be an effective learning tool in studying HoM.

In regard to affective aspects, attempts to investigate individual's affective factors such as attitudes and beliefs become a stepping stone to improve teachers' engagement in incorporating HoM into their teaching practices. In this case, Fraser and Koop (1978) found that teachers gave positive responses to the use of HoM in teaching practice, however, there were still many of them who were not ready to use certain materials in it.

Belief, attitude, emotional states, and values are parts of the affective domain in mathematics education (DeBellis \& Goldin, 2006). Lee (2015) said that prospective teachers' belief needs further cares because it becomes an essentially influential factor of teaching. In line with this view, Schoenfeld (1998) defined belief as a mental construct that represents the codification of individual's understandings and experiences. In connection with attitude, DeBellis \& Goldin (2006) pointed out that attitudes describe the orientations of a certain set of feelings in mathematics context, which can be positive or negative feelings. This one is different from beliefs, in which beliefs involve the attribution of some external validities to the systems of propositions or other cognitive configurations. This is absolutely different from the common viewpoint that assumes attitudes as predispositions toward certain designs of behavior. Furthermore, attitudes have a stable tendency in terms of adjusting the influence of connections and cognitions, whereas beliefs have regularity and are more stable, very cognitive, and relevant with the influence intertwined in them, as well as contributive to the stabilization.

The mathematics curriculum in Indonesian secondary school has not been explicitly integrated in HoM to attain students' basic mathematics competencies. However, the current Indonesian curriculum, namely Kurikulum 2013, has accommodated some historical aspects of mathematics in the learning resources provided by Indonesian government. For example, the official textbook published by Indonesian Ministry of Education and Culture already contains the historical snippets in each chapter of the book, i.e. the exploration of proving Pythagorean Theorem (MoE, 2017). However, Ekawati, Fiangga, \& Siswono (2018) conveyed that the use of HoM in this book is for motivational purposes and information about historical facts and some as resources in reinventing specific mathematics concepts. Nonetheless, the existence of HoM in the national curriculum for secondary school actually has been recognized but its realization remains limited to the use of official textbook. In addition, we found that the HoM aspects used in the textbook has not been applied up to the next level of HoM in Mathematics Education, such as the history-based approach for developing mathematics idea (Man-Keung, 2000).

The emerging intentions of improving mathematics learning process by using HoM have been the interest of some Indonesian researchers. For instance, Fachrudin et al (2019) developed a learning design of Pythagorean Theorem based on problem solving from HoM. Moreover, Fachrudin et al (2018) developed a learning Trajectory of quadratic equations based on Babylonian approach. In addition, the curriculum of teacher education program in Indonesia actually has facilitated the enhancement of prospective teachers' ability in HoM for teaching purposes, even though it has not been integrated in the national curriculum of mathematics education for secondary schools.

The present study focused on the prospective teachers' attitudes and beliefs in using History of Mathematics (HoM) in teaching mathematics. Prospective teachers became the focus of this study as they have already developed a wide range of beliefs about mathematical contents and natures as well as the mathematics teaching and learning experience during their study times. Thus, it will be possibly easier to understand how these beliefs might interact with their beliefs and attitudes toward something deemed as a new program within their course, which is integration of mathematics into pedagogical practice. In addition, the general portrayal of prospective teachers' attitudes and beliefs in using HoM was analyzed to understand the contribution of Indonesian teacher education program on their pedagogical preparedness. Thus, this study aimed to examine Indonesian prospective teachers' attitudes and beliefs in using History of Mathematics (HoM) to teach mathematics.

\section{Materials and Methods}

The present study used cross-sectional survey to reveal the prospective teachers' attitudes and beliefs in using HoM to teach mathematics. Such survey design was relevant as this study did not intend to look at certain attitude and belief changes, which might lead to longitudinal survey.

\subsection{Participants}

305 prospective mathematics teachers who were taking 
mathematics teacher education programs from nine universities in Indonesia were selected as the research respondents based on simple random sampling. The respondents were then to be categorized regarding 'have' or 'have not' taken the History of mathematics (HoM) course. This was to investigate whether or not HoM course in teacher education program influenced their attitudes and beliefs of using HoM in teaching mathematics.

\subsection{Instruments and Data Analysis}

This study used attitudes and beliefs questionnaire adapted from Alpaslan, Işısksal \& Haser (2011) and Alpaslan, Işıksal \& Haser (2014). The validity and reliability of the questionnaire was tested using the Pearson product moment validity test for all items, of which the result of $r$ value was greater than .113, meaning the validity of each item at .01 level. The reliability test of the instruments showed a high reliability $(\alpha=.917)$.

While the initial studies discussed the impacts of gender and education level on prospective teachers' attitudes and beliefs in using HoM in teaching mathematics, the present study analyzed whether the existing experience of 'have taken' or 'have not taken' HoM course in the formal education influenced the level of prospective teachers' attitudes and beliefs. The data were analyzed to investigate the attitudes and beliefs of Indonesian prospective teachers towards the use of history of mathematics in mathematics teaching. The questionnaire did not separate 'Attitude Items' and 'Belief Items' since some items might have overlapped one another related to the definition. The first part of the questionnaires contained demographic questions (e.g. gender, year of study times) and some personal questions about respondents' experience with HoM and its usage for educational purpose. The second part consisted of 33 items of attitude and belief aspects in a form of a five-point Likert's scaling method, which were adapted from Alpaslan et al (2014). The response categories were 'strongly agree' (5), 'agree' (4), 'doubtful' or 'neutral' (3), 'disagree' (2), and 'strongly disagree' (1) for the positive statement category. While the scores for negative statements were 'strongly agree' (1), 'agree' (2), 'doubtful' or 'neutral' (3), 'disagree' (4), and 'strongly disagree' (5).
Thus, the respondents' score would be varied between 33 and 165 . The times given for filling out the questionnaire were 25 minutes.

We classified the level of prospective teachers' attitudes and beliefs in using HoM into three categories namely low, medium, and high. Table 1 describes the score ranges for each level.

Table 1. Classification of attitude and belief levels based on total and average score

\begin{tabular}{|l|c|c|}
\hline Level & $\begin{array}{c}\text { Range of average } \\
\text { score }\end{array}$ & $\begin{array}{c}\text { Range of average } \\
\text { total scores }\end{array}$ \\
\hline Low & $1-2.33$ & $33-77$ \\
\hline Medium & $2.34-3.67$ & $77.01-121$ \\
\hline High & $3.68-5$ & $121.01-165$ \\
\hline
\end{tabular}

\section{Results}

Among 305 respondents, 159 prospective teachers had taken a history of mathematics (HoM) course and the rests had not taken it (see Table 2). In other words, more than half of the prospective teachers got the information about HoM along with the information about its usage for teaching mathematics purpose from their formal education. However, less than $5 \%$ of them actively searched for information or publications about HoM and its usage in learning. Furthermore, the data obtained from the questionnaire were analyzed on the basis of how HoM course in the teacher education program affected the prospective teachers' attitudes and beliefs in using HoM in the classroom activities.

Table 2. Prospective teachers' knowledge of HoM from formal education

\begin{tabular}{|c|c|c|}
\hline \multicolumn{2}{|c|}{$\begin{array}{c}\text { Have you taken History of Mathematics } \\
\text { (HoM) course in your study? }\end{array}$} \\
\hline Answer & Frequency & Percentage \\
\hline Yes & 159 & $52.13 \%$ \\
\hline No & 146 & $47.87 \%$ \\
\hline Total & 305 & $100.00 \%$ \\
\hline
\end{tabular}

Table 3. Presents the comparison of average score and average of total scores based on three groups: all respondents, those who had taken HoM, and those who had not taken HoM course

\begin{tabular}{|c|c|c|c|}
\hline & \multicolumn{2}{|c|}{ Group } \\
\hline $\begin{array}{c}\text { Average of total score of attitudes and beliefs in } \\
\text { using HoM in mathematics learning }\end{array}$ & All respondents & $\begin{array}{c}\text { Have taken HoM } \\
\text { course } \\
\text { course }\end{array}$ & 117.037 \\
\hline $\begin{array}{c}\text { Average score of attitudes and beliefs in using } \\
\text { HoM in mathematics learning }\end{array}$ & 115.387 & 3.5466 \\
\hline
\end{tabular}


Based on the 33 statements in the questionnaires, it was found that the average of total scores of those included in a group 'have taken HoM course' was higher than those who had not taken HoM course, even though both groups were in the category of medium level.

For further analysis, independent sample test was undertaken to reveal whether 'have taken' or 'have not taken' HoM course had a significant effect on the prospective teachers' attitudes and beliefs in using it in teaching mathematics.

Table 4 shows that there were significant differences between the two groups. Some differences involved the prospective teachers in the 'have taken course' group, who gave a high rating on several items, for example 'By integrating the history of Mathematics in mathematics education displays a realistic and comprehensive picture of mathematics itself', 'History of mathematics should be integrated in mathematics learning', and 'Comparison between the old and modern concepts of mathematics helps students understand math', while the 'have not taken' group responded with a medium score.

In accordance with the result of independent sample t-test, prospective teachers who had taken HoM course tent to have higher attitudes and beliefs in using HoM to teach mathematics compared to those who had not taken the course during their formal study times. Those who had not taken the course were due to the fact that the curriculum of some mathematics teacher education programs did not include HoM in the curriculum. Therefore, this study recommended including HoM course as a subject in the teacher education program, especially about the aspects discussing the use of history in learning mathematics.

To underline a number of statement items that have similar respond from all groups of prospective teachers, first, Table 1 describes several statement items that received very positive responses or high scores from the respondents.

Table 4. Independent Sample Test

\begin{tabular}{|c|c|c|c|c|}
\hline & Group & $N$ & Mean $(M)$ & Std. Deviation \\
\hline \multirow{2}{*}{$\begin{array}{c}\text { Attitude and beliefs in using HoM in } \\
\text { Mathematics Teaching }\end{array}$} & Have Taken HoM course & 159 & 3.5466 & .44629 \\
\cline { 2 - 5 } & Have not taken HoM course & 146 & 3.4424 & .46066 \\
\hline
\end{tabular}

\begin{tabular}{|c|c|c|c|c|c|c|c|c|c|c|}
\hline & \multicolumn{2}{|c|}{$\begin{array}{c}\text { Levene's Test for } \\
\text { Equality of } \\
\text { Variances }\end{array}$} & \multicolumn{7}{|c|}{ t-test for Equality of Means } \\
\hline & & \multirow[t]{2}{*}{$F$} & \multirow{2}{*}{ Sig. } & \multirow{2}{*}{$t$} & \multirow{2}{*}{$d f$} & \multirow{2}{*}{$\begin{array}{c}\text { Sig. } \\
\text { (2-tailed) }\end{array}$} & \multirow{2}{*}{$\begin{array}{c}\text { Mean } \\
\text { Difference }\end{array}$} & \multirow{2}{*}{$\begin{array}{l}\text { Std. Error } \\
\text { Difference }\end{array}$} & \multicolumn{2}{|c|}{$\begin{array}{c}95 \% \text { Confidence Interval } \\
\text { of the Difference }\end{array}$} \\
\hline & & & & & & & & & Lower & Upper \\
\hline \multirow{2}{*}{$\begin{array}{l}\text { Attitudes and } \\
\text { beliefs in using } \\
\text { HoM in } \\
\text { Mathematics } \\
\text { Teaching }\end{array}$} & $\begin{array}{c}\text { Equal } \\
\text { variances } \\
\text { assumed }\end{array}$ & .485 & .487 & 2.006 & 303 & .046 & .10421 & .05195 & .00198 & .20644 \\
\hline & $\begin{array}{c}\text { Equal } \\
\text { variances not } \\
\text { assumed }\end{array}$ & & & 2.003 & 298.894 & .046 & .10421 & .05202 & .00183 & .20658 \\
\hline
\end{tabular}


Table 5. Statement Items that Had Similar Responses from All Groups of Prospective Teachers

\begin{tabular}{|l|c|c|c|}
\hline \multirow{2}{*}{ Statements } & \multicolumn{3}{|c|}{ Average score of positive response } \\
\cline { 2 - 4 } & All participants & $\begin{array}{c}\text { Have taken HoM } \\
\text { course }\end{array}$ & $\begin{array}{c}\text { Have not taken } \\
\text { HoMcourse }\end{array}$ \\
\hline $\begin{array}{l}\text { Having knowledge of the history of mathematics gives an idea of } \\
\text { the importance of mathematics in everyday life. }\end{array}$ & 3.85 & 3.83 & 3.88 \\
\hline $\begin{array}{l}\text { The use of history of mathematics in classroom contributes } \\
\text { positively to the mathematics learning by providing the different } \\
\text { views and ways in presenting certain material. }\end{array}$ & 3.84 & 3.91 & 3.77 \\
\hline $\begin{array}{l}\text { Realizing that the great mathematicians also made a mistake (in } \\
\text { mathematics) can increase student's motivation in learning } \\
\text { mathematics. }\end{array}$ & 3.87 & 3.92 & 3.82 \\
\hline $\begin{array}{l}\text { Studying the history of mathematics can enrich the prospective } \\
\text { teachers' knowledge in preparing the learning material. }\end{array}$ & 3.99 & 3.04 & 3.94 \\
\hline $\begin{array}{l}\text { Prospective teachers must be given a course on how to use the } \\
\text { history of mathematics in mathematics education. }\end{array}$ & 3.71 & 3.72 & 3.70 \\
\hline $\begin{array}{l}\text { The history of mathematics lets the students connect among } \\
\text { mathematical concepts and see the close relationship between } \\
\text { these concepts. }\end{array}$ & 3.81 & 3.87 & 3.74 \\
\hline $\begin{array}{l}\text { The history of mathematics makes students realize that } \\
\text { mathematics is a universal product of various cultures and } \\
\text { civilizations. }\end{array}$ & 3.84 & 3.89 & 3.79 \\
\hline $\begin{array}{l}\text { The history of mathematics helps understand the role and } \\
\text { importance of mathematics in society. }\end{array}$ & 3.80 & 3.88 & 3.83 \\
\hline $\begin{array}{l}\text { The history of mathematics allows students to reinvent the } \\
\text { concept of mathematics by using their talents and experiences. }\end{array}$ & 3.77 & 3.77 & 3.75 \\
\hline $\begin{array}{l}\text { Prospective Teachers should have knowledge and idea of the } \\
\text { development of the concepts. }\end{array}$ & 3.72 \\
\hline
\end{tabular}

Table 6. Some Statement Items where All Groups Showed Low Score

\begin{tabular}{|l|c|c|c|}
\hline Statements & \multicolumn{3}{|c|}{ Average score of negative responses } \\
\hline & All participants & $\begin{array}{c}\text { Have taken HoM } \\
\text { course }\end{array}$ & $\begin{array}{c}\text { Have not taken } \\
\text { HoM course }\end{array}$ \\
\hline $\begin{array}{l}\text { It is difficult to integrate the history of mathematics into } \\
\text { mathematics education. }\end{array}$ & 3.05 & 3.09 & 3.00 \\
\hline $\begin{array}{l}\text { I do not have any idea about how to use the history of } \\
\text { mathematics in classroom (eg, tangram, proof of } \\
\text { Pythagoras, the use of tile algebra al khawarizmi, etc.). }\end{array}$ & 3.11 & 3.18 & 3.03 \\
\hline $\begin{array}{l}\text { I do not know how to integrate the history of mathematics } \\
\text { into the process of learning mathematics. }\end{array}$ & 3.07 & 3.13 & 3.00 \\
\hline $\begin{array}{l}\text { I do not have enough information about the historical } \\
\text { evolution of the concepts that I will teach in the future. }\end{array}$ & 2.84 & 2.82 & 3.86 \\
\hline $\begin{array}{l}\text { Integrating history of mathematics into teaching } \\
\text { mathematics increases students' anxiety. }\end{array}$ & 3.28 & 3.38 & 3.17 \\
\hline $\begin{array}{l}\text { If the history of mathematics is integrated with } \\
\text { mathematics education curriculum in schools, it will } \\
\text { increase the burden of teachers and students. }\end{array}$ & 3.08 & 3.11 & 3.06 \\
\hline $\begin{array}{l}\text { History of mathematics-based learning activities does not } \\
\text { attract the students' interest. }\end{array}$ & 3.19 & 3.22 & 3.19 \\
\hline $\begin{array}{l}\text { I do not think of to perform a teaching using history of } \\
\text { mathematics-based activities. }\end{array}$ & 3.16 & 3.34 & 3.10 \\
\hline Doing history -based mathematics learning is wasting time. & 3.27 & 117.89 & 3.20 \\
\hline Total score & 116.27 & & 114.51 \\
\hline
\end{tabular}

Among the 33 items in the questionnaires, the prospective teachers, regardless they had been taught HoM or not, had a very positive response for 10 statements. Table 5 shows that all groups agreed that the integration of HoM into mathematics learning brought a positive impact in terms of student's motivation, quality, and meaningfulness of mathematics learning in class. Moreover, it helped students' understand the mathematical concepts.

However, Table 6 portrays some statement items where all groups showed low scores. 


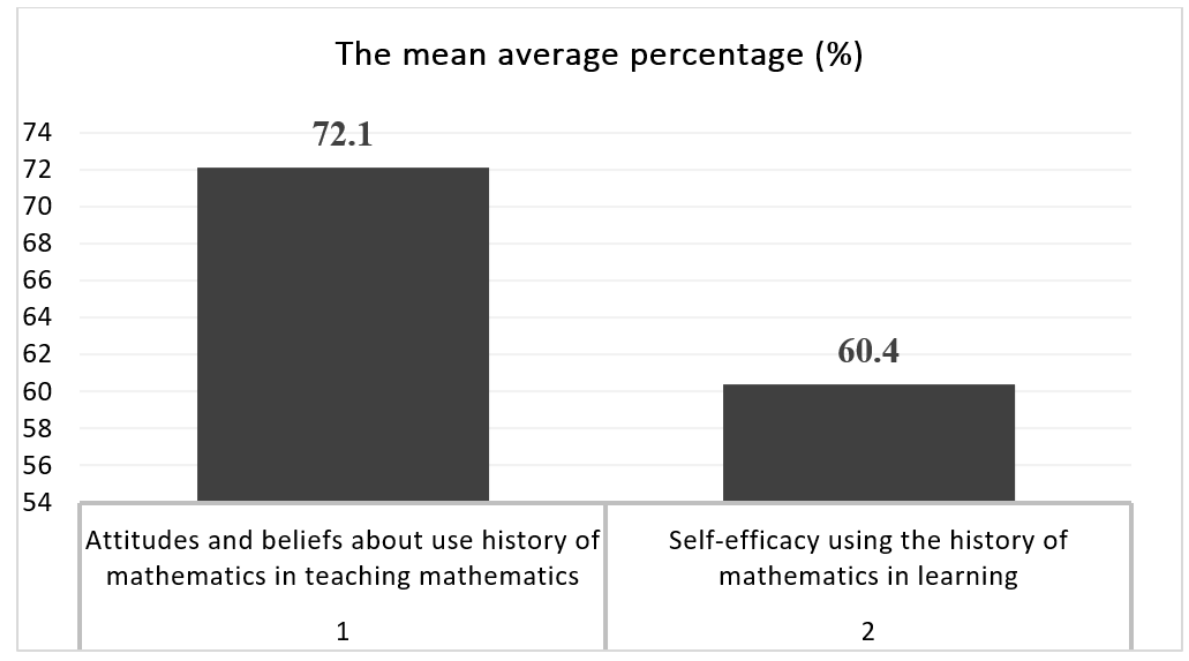

Figure 1. The Comparison between 'Attitude and Belief' and 'Self-efficacy'

Table 6 portrays that some statement items that got a low scores included 'I do not have an idea about how to use the history of mathematics in classroom', 'I do not know how to integrate the history of mathematics into the process of learning mathematics', 'I do not have enough information about the historical evolution of the concepts that I will teach in the future', and 'I do not think of to perform a teaching using history of mathematics-based activities'. These statements were actually intended to explore the teachers' self-efficacy in using HoM to teach mathematics. Therefore, this study revealed that both prospective teachers who had taken and not taken the HoM course still had low self-efficacy in integrating HoM into learning. Figure 1 describes the comparison between average score of self-efficacy and non self-efficacy items of Indonesian prospective teachers.

The prospective teachers' responses on the statement items related to the attitudes and beliefs in using HoM to teach mathematics were generally positive $(72.10 \%)$. However, the statement items related to prospective teachers' self-efficacy in using HoM were still low $(60.40 \%)$. This was due to the fact that the teachers did not know and felt difficult to find the idea of how to integrate HoM into learning. Lacks of knowledge and experience of using HoM might make them feel difficult in applying HoM for learning purposes. Furthermore, this caused the level of prospective teachers' attitudes and beliefs at medium level.

Related to the prospective teachers' ability in using HoM for teaching mathematics, the respondents were asked about their ideas of using HoM on certain topics in mathematics. They were given some examples of HoM that they knew to be integrated into mathematics learning such as Pythagoras, al Khawarizmi, Fibonacci, and Euclid. Most of them chose Pythagoras as one of the examples of mathematics learning that must be integrated with HoM. However, most of them were not able to mention in details about how the idea was integrated. Based on the analysis, their ability to mention in details about how the idea was integrated with HoM to teach mathematics remained low. Although, more than half of them got the information about HoM and received information about its usage for teaching purpose. Unfortunately, their ability was still low. This showed that the improvement of HoM course was required in order to realize qualified teacher education program in Indonesia. By evaluating HoM course, the prospective teachers' abilities related to the history of mathematics along with its usage for teaching purposes could be elevated.

The results of Indonesian prospective teachers' attitudes and beliefs in using HoM were in accordance with a research conducted in Turkey, of which the result showed that prospective teacher generally had positive attitudes and beliefs in mathematics education (Alpaslan et al, 2014). Such positive attitudes and beliefs should be perceived since the aspects would be essential in supporting their future professional career as mathematics teacher. Unfortunately, still many of them realized that they had not had sufficient information about the issues.

The low score of self-efficacy in using HoM to teach mathematics showed that they needed to be exposed in numbers of training to accelerate their self-efficacy in using HoM to teach mathematics. Therefore, the teacher education program or college must take advantage of these positive attitudes and beliefs to provide more training for prospective teachers about HoM along with its usage in teaching mathematics. Courses related to HoM should also be given to prospective teachers, for instance, the ideas about how to apply history in teaching and learning process. Thus, the prospective teachers could consider HoM as an alternative solution in their future teaching practice and an effort to develop attitudes and beliefs in using HoM in classroom activities.

\section{Conclusions}

Indonesian prospective teachers' attitudes and beliefs in 
using the history of mathematics (HoM) in teaching mathematics are at a medium level. Although, statement items related to self-efficacy in using HoM are still relatively low, whereas the statement items about attitudes and beliefs in using HoM shows positive results. This is due to the lack of knowledge perceived by prospective teachers during lectures about the use of HoM in classroom activities. A number of researchers have conducted studies on prospective teachers' positive attitudes and beliefs along with the benefits of using HoM to teach mathematics such as Man-Keung (2000), Fauvel \& Van Maanen (2000), Jankvist (2009), of which the results could be a reference for the teacher education program or college to use HoM and its application during classroom activities.

Considering the low performance of Indonesian prospective teachers related to the pedagogical knowledge of HoM, the present study suggests the colleges, especially for mathematics teacher education program, to provide a lecture model for the topic of HoM. The model can improve the prospective teachers' ability through designing the learning trajectory based on history of mathematics by following the step of design research. We find the correlation of the stages of the designing process of design research based on Gravemeijer \& Cobb (2006) and introducing History of Mathematics in mathematics education based on Furinghetti (2000) (see figure 2). Furthermore, the design can be used as a theory for designing and preparing prospective teachers in using HoM to develop the learning trajectory.

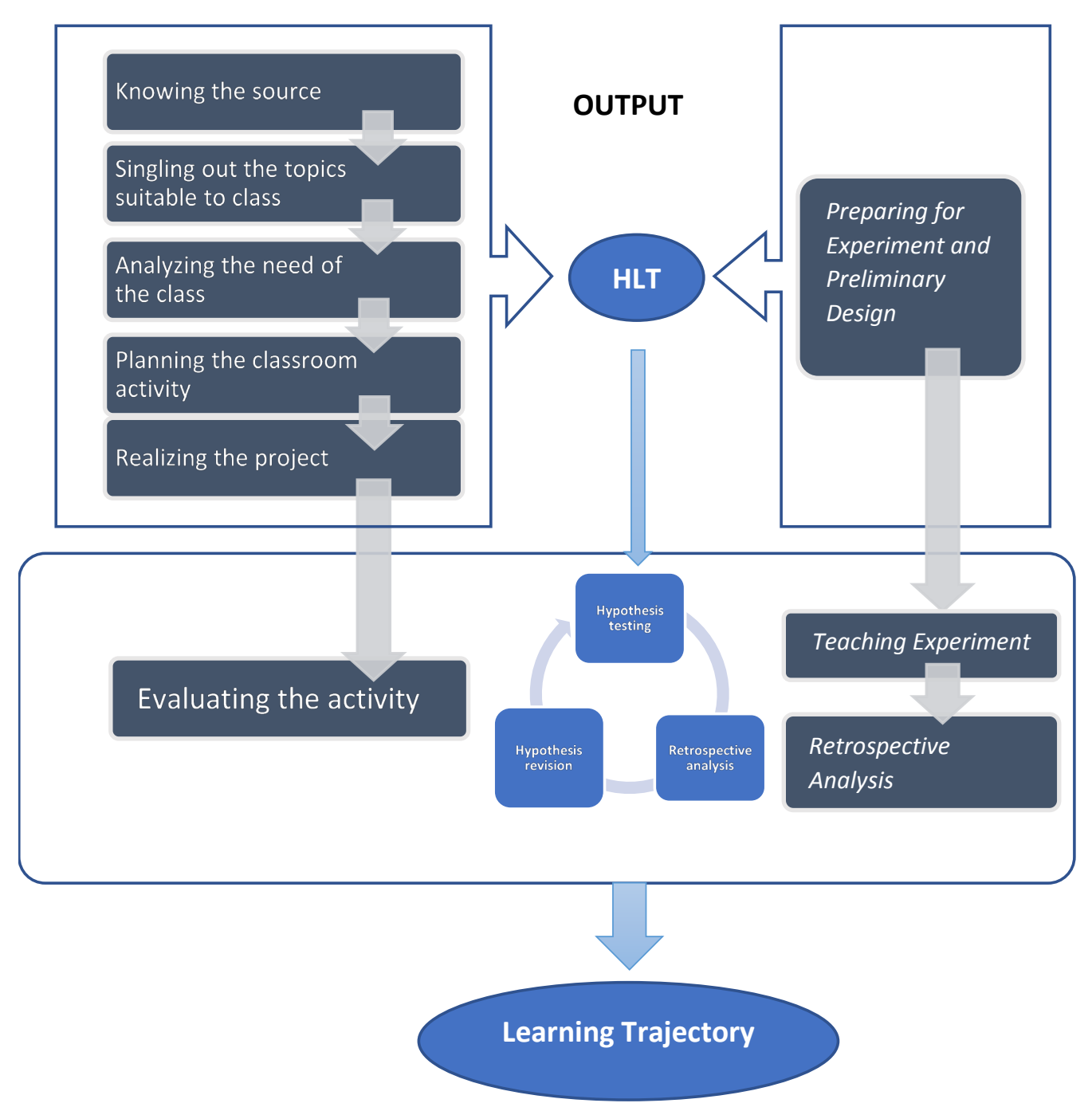

Figure 2. The Correlation of the Designing Process of "Design Research" and process of introducing History of Mathematics in mathematics education 
By introducing how to develop the design of history-based learning trajectory, Indonesian prospective teachers' pedagogical knowledge and self-efficacy will increase gradually. Moreover, they can use the history of mathematics (HoM) in teaching mathematics up to the development stage of mathematics ideas based on Man-keung (2000) or history-based approach based on Jankvist (2009).

\section{Acknowledgments}

The authors would like to thank the Ministry of Research, Technology, and Higher Education of the Republic of Indonesia (Kemenristekdikti) for financially supporting this research.

\section{Appendix}

The data of beliefs and attitudes questionnaire

\begin{tabular}{|c|c|c|c|c|}
\hline \multirow[t]{2}{*}{ No } & \multirow[t]{2}{*}{ Statement } & \multicolumn{3}{|c|}{ Average score of positive response } \\
\hline & & All participants & $\begin{array}{l}\text { Have taken HoM } \\
\text { course group }\end{array}$ & $\begin{array}{l}\text { Have not taken } \\
\text { HoM course group }\end{array}$ \\
\hline 1 & $\begin{array}{l}\text { It is difficult to integrate the history of mathematics into } \\
\text { mathematics education }\end{array}$ & 3.05 & 3.09 & 3.00 \\
\hline 2 & $\begin{array}{l}\text { Having knowledge of the history of mathematics gives an } \\
\text { idea of the importance of mathematics in life }\end{array}$ & 3.85 & 3.83 & 3.88 \\
\hline 3 & $\begin{array}{l}\text { The use of history of mathematics in classroom provides } \\
\text { contributes positively to the mathematics learning by } \\
\text { providing the different angle of view and way in presenting } \\
\text { certain material }\end{array}$ & 3.84 & 3.91 & 3.77 \\
\hline 4 & $\begin{array}{l}\text { Using the history of mathematics in learning mathematics } \\
\text { causes students lose their enthusiasm in learning } \\
\text { mathematics }\end{array}$ & 3.53 & 3.54 & 3.52 \\
\hline 5 & $\begin{array}{l}\text { Realizing that the great mathematicians also made a mistake } \\
\text { (in mathematics ) can increase the motivation of students in } \\
\text { learning mathematics }\end{array}$ & 3.87 & 3.92 & 3.82 \\
\hline 6 & $\begin{array}{l}\text { Studying the history of mathematics can enrich the } \\
\text { prospective teachers' knowledge in preparing the learning } \\
\text { material }\end{array}$ & 3.99 & 4.04 & 3.94 \\
\hline 7 & $\begin{array}{l}\text { Prospective teachers must be given a course on how to use } \\
\text { the history of mathematics in mathematics education }\end{array}$ & 3.71 & 3.72 & 3.70 \\
\hline 8 & $\begin{array}{l}\text { The history of mathematics allows the students to connect } \\
\text { mathematical concepts and see the close relationship } \\
\text { between these concepts }\end{array}$ & 3.81 & 3.87 & 3.74 \\
\hline 9 & $\begin{array}{l}\text { The history of mathematics makes students realize that } \\
\text { mathematics is a universal product of various cultures and } \\
\text { civilizations }\end{array}$ & 3.84 & 3.89 & 3.79 \\
\hline 10 & $\begin{array}{l}\text { I do not have an idea about how to use the history of } \\
\text { mathematics in classroom (eg, tangram, proof of } \\
\text { Pythagoras, the use of tile algebra al khawarizmi etc. ) }\end{array}$ & 3.11 & 3.18 & 3.03 \\
\hline 11 & $\begin{array}{l}\text { I do not know how to integrate the history of mathematics } \\
\text { into the process of learning mathematics }\end{array}$ & 3.07 & 3.13 & 3.00 \\
\hline 12 & $\begin{array}{l}\text { By integrating the history of Mathematics in mathematics } \\
\text { education displays a realistic and comprehensive picture of } \\
\text { mathematics itself }\end{array}$ & 3.66 & 3.77 & 3.55 \\
\hline 13 & $\begin{array}{l}\text { Realistic problem from the history of mathematics should be } \\
\text { used in the education of mathematics }\end{array}$ & 3.60 & 3.65 & 3.55 \\
\hline 14 & $\begin{array}{l}\text { The history of mathematics is a practical tool to teach } \\
\text { mathematics }\end{array}$ & 3.46 & 3.52 & 3.40 \\
\hline 15 & $\begin{array}{l}\text { History of mathematics should be integrated in mathematics } \\
\text { learning }\end{array}$ & 3.68 & 3.73 & 3.62 \\
\hline 16 & $\begin{array}{l}\text { I do not have enough information about the historical } \\
\text { evolution of the concepts that I will teach in the future }\end{array}$ & 2.84 & 2.82 & 2.86 \\
\hline 17 & $\begin{array}{l}\text { The didactical written and visual material can be developed } \\
\text { by using the history of mathematics (for example, pieces of } \\
\text { work students, games, puzzles, video documentaries, etc.) }\end{array}$ & 3.59 & 3.65 & 3.52 \\
\hline 18 & $\begin{array}{l}\text { The history of mathematics helps to understand the role and } \\
\text { importance of mathematics in society }\end{array}$ & 3.80 & 3.88 & 3.72 \\
\hline 19 & Integrating history of mathematics into teaching & 3.28 & 3.38 & 3.17 \\
\hline
\end{tabular}




\begin{tabular}{|c|c|c|c|c|}
\hline & mathematics increases students' anxiety & & & \\
\hline 20 & $\begin{array}{l}\text { The inclusion of the history of mathematics in the education } \\
\text { of mathematics disrupts the process of learning mathematics }\end{array}$ & 3.50 & 3.64 & 3.35 \\
\hline 21 & $\begin{array}{l}\text { The history of mathematics allows students to reinvent the } \\
\text { concept of mathematics by using their the talents and } \\
\text { experiences }\end{array}$ & 3.77 & 3.83 & 3.71 \\
\hline 22 & $\begin{array}{l}\text { If the history of mathematics is integrated with mathematics } \\
\text { education curriculum in schools, it will increase the burden } \\
\text { of teachers and students }\end{array}$ & 3.08 & 3.11 & 3.06 \\
\hline 23 & $\begin{array}{l}\text { Investigating original sources of mathematics allows } \\
\text { teachers and students to pay attention to the advantages of } \\
\text { modern mathematics }\end{array}$ & 3.53 & 3.58 & 3.49 \\
\hline 24 & $\begin{array}{l}\text { History of mathematics-based Learning activities does not } \\
\text { attract the students' interest }\end{array}$ & 3.19 & 3.19 & 3.19 \\
\hline 25 & $\begin{array}{l}\text { History of Mathematics helps change the atmosphere of } \\
\text { learning in the classroom from just transferring knowledge } \\
\text { to constructing knowledge }\end{array}$ & 3.63 & 3.64 & 3.62 \\
\hline 26 & $\begin{array}{l}\text { History -based learning activities must be included in the } \\
\text { mathematics education curriculum }\end{array}$ & 3.39 & 3.40 & 3.37 \\
\hline 27 & $\begin{array}{l}\text { Prospective Teachers should have knowledge and idea of } \\
\text { the development of the concepts }\end{array}$ & 3.77 & 3.85 & 3.68 \\
\hline 28 & $\begin{array}{l}\text { The history of mathematics makes us pay attention to the } \\
\text { contributions of mathematics to the other discipline of } \\
\text { science ( e.g. Astronomy ) and the relationship }\end{array}$ & 3.62 & 3.67 & 3.57 \\
\hline 29 & $\begin{array}{l}\text { Comparison between the old and modern concepts of } \\
\text { mathematics helps students understand math }\end{array}$ & 3.68 & 3.72 & 3.64 \\
\hline 30 & $\begin{array}{l}\text { I do not think of to perform a teaching using history of } \\
\text { mathematics-based activities }\end{array}$ & 3.16 & 3.22 & 3.10 \\
\hline 31 & Doing history -based mathematics learning is wasting time & 3.27 & 3.34 & 3.20 \\
\hline 32 & $\begin{array}{l}\text { Knowing the developments of certain topics in mathematics } \\
\text { which is being studied allows students to study the topic } \\
\text { better }\end{array}$ & 3.57 & 3.60 & 3.54 \\
\hline \multirow[t]{2}{*}{33} & $\begin{array}{l}\text { İt is not important to integrate the history of mathematics } \\
\text { into teaching mathematics }\end{array}$ & 3.50 & 3.59 & 3.41 \\
\hline & Total score & 116.27 & 117.89 & 114.51 \\
\hline
\end{tabular}

\section{REFERENCES}

[1] Alpaslan, M., Isiksal, M., \&Haser, C. (2011). The development of attitudes and beliefs questionnaire towards using history of mathematics in mathematics education. In Proceedings of the seventh congress of the European society for research in mathematics education (pp. 1661-1669).

[2] Alpaslan, M., Işıksal, M., \&Haser, Ç. (2014). Pre-service mathematics teachers' knowledge of history of mathematics and their attitudes and beliefs towards using history of mathematics in mathematics education. Science \& Education, 23(1), 159-183.

[3] Bütüner, S. Ö. (2016). The use of concrete learning objects taken from the history of mathematics in mathematics education. International Journal of Mathematical Education in Science and Technology, 47(8), 1156-1178.

[4] Clark, K. M. (2012). History of mathematics: Illuminating understanding of school mathematics concepts for prospective mathematics teachers. Educational Studies in Mathematics, 81(1), 67-84.

[5] DeBellis, V. A., \& Goldin, G. A. (2006). Affect and meta-affect in mathematical problem solving: Are presentational perspective. Educational Studies in Mathematics, 63, 131-147.

[6] Ekawati, R., Fiangga, S., \& Siswono, T. Y. E. (2018, November). Historical aspect of mathematics on Indonesian mathematics textbook. In IOP Conference Series: Materials Science and Engineering (Vol. 434, No. 1, p. 012001). IOP Publishing.

[7] Fachrudin, A. D., \& Putri, R. I. I. (2014). Building Students' Understanding of Quadratic Equation Concept Using Naïve Geometry. Indonesian Mathematical Society Journal on Mathematics Education, 5(2), 192-202.

[8] Fachrudin, A. D., Putri, R. I. I., Kohar, A. W., \&Widadah, S. (2018). Developing a Local Instruction Theory for Learning the Concept of Solving Quadratic Equation Using Babylonian Approach. In Journal of Physics: Conference Series (Vol. 1108, No. 1, p. 012069). IOP Publishing.

[9] Fachrudin, A. D., Ekawati, R., Kohar, A. W., Widadah, S., Kusumawati, I. B., \& Setianingsih, R. (2019, December). Ancient China history-based task to support students' geometrical reasoning and mathematical literacy in learning Pythagoras. In Journal of Physics: Conference Series (Vol. 1417, No. 1, p. 012042). IOP Publishing.

[10] Fauvel, J., \& van Maanen, J. A. (Eds.). (2006). History in mathematics education: The ICMI study (Vol. 6). Springer 
Science \& Business Media.

[11] Fraser, B. J., \& Koop, A. J. (1978). Teachers' opinions about some teaching material involving history of mathematics. International Journal of Mathematical Education in Science and Technology, 9(2), 147-151.

[12] Gravemeijer, K., \& Cobb, P. (2006). Design research from a learning design perspective. Educational design research, 17-51.

[13] Jankvist, U. T. (2009). A categorization of the "whys" and "hows" of using history in mathematics education. Educational studies in Mathematics, 71(3), 235-261.

[14] Lee, I. (2015). Student teachers' changing beliefs on a pre-service teacher education course in Hong Kong. In Experiences of second language teacher education (pp. 15-41). Palgrave Macmillan, London.

[15] Man-Keung, S. (2000). The ABCD of using history of mathematics in the (undergraduate) classroom. PALEONTOLOGICAL SOCIETY PAPERS, 6, 3-10.

[16] Ministry of Educatio (MoE). (2017). Buku Matematikauntuk Kelas VIII SMP (Mathematics Book for Junior High School. Jakarta: MoE.

[17] Schoenfeld, A. H. (1998). Toward a theory of teaching-in-context. Issues in education, 4(1), 1-94.

[18] Wang, K., Wang, X. Q., Li, Y., \& Rugh, M. S. (2018). A framework for integrating the history of mathematics into teaching in Shanghai. Educational Studies in Mathematics, 98(2), 135-155

[19] Zengin, Y. (2018). Incorporating the dynamic mathematics software GeoGebra into a history of mathematics course. International Journal of Mathematical Education in Science 